\title{
ANALISIS TINDAK TUTUR EKSPRESIF DALAM ANIME SERVANT X SERVICE (EPISODE 1 SAMPAI 13)
}

\author{
S. Untiani ${ }^{1}$, K.E.K. Adnyani ${ }^{2}$, N.N. Suartini ${ }^{3}$ \\ Jurusan Bahasa Asing, Universitas Pendidikan Ganesha, Singaraja \\ e-mail: Sitiuntiani@undiksha.ac.id krisna.adnyani@undiksha.ac.id nnsuartini@undiksha.ac.id
}

\begin{abstract}
ABSTRAK
Penelitian ini bertujuan untuk mendeskripsikan fungsi tindak tutur ekspresif berdasarkan strategi kesopanan dan bentuk tindak tutur ekspresif dalam anime Servant $x$ Service (episode 1 sampai 13). Data dikumpulkan dengan menggunakan metode simak dan catat. Kemudian untuk fungsi tindak tutur ekspresif berdasarkan strategi kesopanan dan bentuk tindak tutur ekspresif dianalisis menggunakan metode padan intralingual. Berdasarkan hasil penelitian menunjukkan bahwa terdapat enam kategori tindak tutur ekspresif, yakni mengeluh, menyindir, memuji, meminta maaf, membanggakan diri, dan mengucapkan terima kasih dalam anime Servant $x$ Service (episode 1 sampai 13). Kemudian bentuk tindak tutur yang ditemukan adalah langsung literal, tidak langsung literal dan langsung tidak literal.
\end{abstract}

Kata Kunci: Fungsi Tindak Tutur Ekspresif; Strategi Kesopanan; Bentuk Tindak Tutur Ekspresif

\section{要旨}

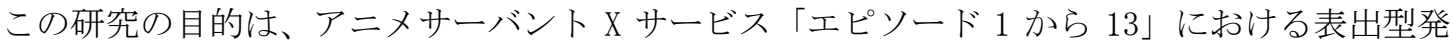
語行為の機能礼儀正しさの戦略に基づく表出型発語行為の種類を明らかにすることです。データは、 ノートに記録して、視聴により収集し、それを言語内同等法により分析した。分析した結果、アニメ

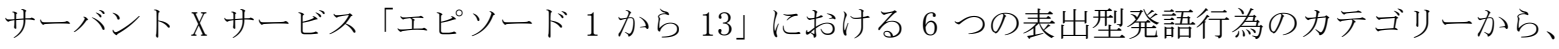

「文句を言う」、「ほのめか寸」、「賞賛」、「謝罪」、「自慢」、「感謝を言う」礼儀正しさの戦 略という「正の礼儀」及び「負の礼儀」がある。それに、表出型発語行為で 直接の文字通り、間接 的な文字通り、間接的な形式の発話行為も出た。

キーワード : 表出型発語行為の機能、機能礼儀正しさの戦略表、出型発語行為

\section{Pendahuluan}

Bahasa sering digunakan manusia sebagai makhluk sosial untuk berkomunikasi dalam kehidupan bermasyarakat. Komunikasi yang dilakukan akan menghasilkan sebuah percakapan dan dapat mengakibatkan adanya tindak tutur. Komunikasi bisa berjalan dengan lancar apabila makna tuturannya bisa dipahami oleh mitra tutur. Searle (1979:13) menyebutkan bahwa tindak tutur ekspresif mempunyai fungsi agar penutur bisa mengungkapkan sikap psikologisnya terhadap mitra tutur dalam keadaan tersirat.

Aspek perasaan manusia biasanya bisa disembunyikan dan memiliki makna tersirat sehingga membutuhkan pemahaman lebih untuk mengetahui apa yang dimaksudkan oleh penutur. Dengan adanya penelitian ini diharapkan hasil analisis mengenai tindak tutur ekspresif dapat dijadikan pembelajaran terutama dalam bahasa Jepang.

Dalam tindak tutur ekspresif, kesopanan merupakan salah satu aspek yang penting dalam komunikasi. Kesopanan dalam interaksi dapat didefinisikan sebagai alat yang digunakan untuk menunjukkan kesadaran tentang wajah orang lain (Yule 2006:104). Wajah merupakan wujud pribadi seseorang dalam masyarakat yang mengacu pada makna sosial dan emosional setiap orang dan mengharapkan orang lain untuk mengetahuinya.

Tindak tutur ekspresif bisa memiliki bentuk tuturan langsung atau tidak langsung. Dalam tindak tutur juga terdapat bentuk tuturan literal dan tidak literal. Fungsi tindak tutur ekspresif dapat memiliki bentuk yang berbeda. 
Dalam penelitian ini, anime Servant $x$ Service dipilih karena menampilkan situasi atau keadaan perasaan seseorang di kantor Pegawai Negeri Sipil. Tuturan ekspresif yang ditemukan berdasarkan latar belakang tokoh yang ada di dalam anime ini, interaksi yang terjadi dipengaruhi oleh keadaan lingkungan yang terdapat di sekitarnya maupun lawan tuturnya. Anime ini menampilkan fungsi tindak tutur ekspresif yang berbeda-beda sehingga dapat mempengaruhi cara berkomunikasi dalam bahasa Jepang dan bisa digunakan sebagai media pembelajaran.

Berdasarkan pernyataan diatas terdapat dua rumusan masalah, yaitu:

1. Apa sajakah fungsi tindak tutur ekspresif bahasa Jepang berdasarkan prinsip kesopanan yang terdapat dalam anime Servant $x$ Service?

2. Bagaimanakah bentuk tindak tutur ekspresif bahasa Jepang yang terdapat dalam anime Servant $x$ Service?

Adapun tujuan dalam penelitian ini yaitu: 1) untuk menganalisis fungsi tindak tutur ekspresif bahasa Jepang berdasarkan prinsip kesopanan yang terdapat dalam anime Servant $x$ Service. 2) Untuk menganalisis bentuk tindak tutur ekspresif bahasa Jepang yang terdapat dalam anime Servant $x$ Service.

\section{Pragmatik}

Teori yang digunakan dalam penelitian ini adalah teori pragmatik. Menurut Leech (1993:8) Pragmatik adalah studi tentang makna dalam hubungannya dengan situasi-situasi ujar (speech situations). Pragmatik memiliki hubungan dengan penutur atau pemakai bahasa. Berdasarkan pernyataan tersebut pragmatik merupakan ilmu bahasa yang mempelajari struktur bahasa pada sebuah kalimat yang digunakan dalam berkomunikasi dilihat dari konteks dan situasi digunakannya kalimat tersebut.

\section{Tindak Tutur}

Tindak tutur merupakan bagian dari pragmatik. Yule (2006:82) mengemukakan bahwa tindak tutur adalah tindakan-tindakan yang ditamplikan lewat tuturan. Tindak tutur yang memiliki maksud tertentu tersebut tidak dapat dipisahkan dari konsep situasi tutur.

\section{Jenis-jenis Tindak Tutur}

Menurut Austin (1955:145) tindak tutur atas tiga klasifikasi, yaitu tindak tutur lokusi, tindak tutur ilokusi, dan tindak tutur perlokusi. Searle (1979:13) mengelompokkan tindak tutur ilokusi menjadi 5 jenis yaitu asertif, direktif, komisif, ekspresif, deklaratif.

\section{Tindak Tutur Ekspresif}

Searle (1979:13) menyebutkan bahwa tindak tutur ekspresif mempunyai fungsi agar penutur bisa mengungkapkan sikap psikologisnya terhadap mitra tutur dalam keadaan tersirat. Tersirat menurut KBBI memiliki arti 'tersembunyi'. Keadaan tersirat yaitu keadaan ketika penutur mengungkapkan sesuatu tidak secara gamblang, butuh pemahaman lebih mendalam agar mitra tutur dapat mengetahui apa maksud dari tuturan ekspresif yang diungkapkan oleh penutur.

\section{Aspek-aspek Situasi Ujaran}

Setelah mengetahui bahwa pragmatik menelaah makna dalam kaitannya dengan situasi ujaran, maka acuan terhadap satu atau lebih aspek-aspek berikut ini merupakan suatu kriteria. Leech (1993:19). menyebutkan aspek-aspek tutur tersebut antara lain: penutur dan mitra tutur, konteks tuturan, tujuan tuturan, tindak tutur sebagai bentuk aktivitas, tuturan sebagai produk tindak verbal. 
JPBJ, Vol. 7 No. 1, Februari 2021

ISSN: 2613-9618

\section{Bentuk Tindak Tutur}

Wijana dan Rohmadi (2011:28-35) mengklasifikasikan tindak tutur menjadi beberapa bentuk, yaitu : 1) tindak tutur langsung dan tidak langsung 2) tindak tutur literal dan tindak tutur tidak literal. Bila tindak tutur langsung dan tidak langsung diinterseksikan dengan tindak tutur literal dan tidak literal, akan didapatkan tindak tutur-tindak tutur berikut ini, yaitu: a) tindak tutur langsung literal. b) tindak tutur tidak langsung literal. c) tindak tutur langsung tidak literal. d) tindak tutur tidak langsung tidak literal

\section{Kesopanan}

Brown dan Levinson (1987:61) menyatakan bahwa face 'muka' merupakan citra diri yang bersifat umum yang dimiliki oleh setiap warga masyarakat, meliputi muka negatif dan muka positif.

\section{Strategi Kesopanan Positif}

Dalam hal strategi kesopanan positif, Brown dan Levinson (1987. 101-103) mengungkapkan bahwa kesopanan positif terjadi dalam suatu kelompok yang partisipannya memiliki tujuan, keinginan atau latar belakang pengetahuan yang sama. Terdapat beberapa strategi untuk mengurangi kekecewaan mitra tutur, atau dengan kata lain, beberapa strategi agar wajah positif mitra tutur tidak terancam, yaitu: memerhatikan minat, keinginan, kelakuan, dan barang-barang lawan tutur, melebih-lebihkan ketertarikan penutur pada lawan tutur, meningkatkan rasa tertarik terhadap lawan tutur, menggunakan penanda yang menunjukkan jati diri atau kelompok, mencari dan mengusahakan persetujuan lawan tutur, menghindari pertentangan dengan lawan tutur, menimbulkan persepsi sejumlah persamaan penutur dan lawan tutur, membuat lelucon, membuat persepsi bahwa penutur memahami keinginan lawan tuturnya, membuat penawaran dan janji, menunjukkan rasa optimistik, berusaha melibatkan lawan tutur dan penutur dalam suatu kegiatan, meminta dan memberi alasan, menawarkan suatu tindakan timbal balik, memberikan rasa simpati terhadap lawan tutur.

\section{Strategi Kesopanan Negatif}

Strategi kesopanan negatif digunakan untuk mengurangi pelanggaran wajah negatif lawan tutur, dapat dilakukan dengan beberapa strategi yaitu: ungkapan tidak langsung sesuai konvensi. Strategi ini mengacu pada kalimat perintah dari penutur terhadap lawan tuturnya, gunakan bentuk pertanyaan dengan partikel tertentu, lakukan secara hati-hati dan jangan terlalu optimistik, kurangi daya ancaman terhadap wajah lawan tutur, beri penghormatan, gunakan permohonan maaf, jangan menyebutkan penutur dan lawan tutur, nyatakan tindakan mengancam wajah sebagai suatu ketentuan sosial yang umum berlaku nominalkan pernyataan, nyatakan secara jelas bahwa penutur telah memberikan kebaikan atau tidak kepada lawan tutur.

\section{Metode}

Pendekatan yang digunakan dalam penelitian ini adalah pendekatan kualitatif. Metode ini digunakan karena dalam menganalisis tindak tutur ekspresif tidak lepas kaitannya dengan konteks, tuturan bahasa, persepsi dan prilaku dari penutur maupun mitra tutur. Sumber data dalam penelitian ini adalah anime Jepang yang berjudul Servant $x$ Service. Anime ini terdiri dari 13 episode berdurasi 23 menit. Data yang dimaksud adalah tuturantuturan yang termasuk ke dalam fungsi dan bentuk tindak tutur ekspresif yang terdapat pada episode 1 sampai 3. Data yang diperoleh akan dimasukkan ke dalam instrumen penelitian berupa kartu data. Metode pengumpulan data yang akan digunakan peneliti yaitu metode simak dan catat. Metode simak adalah metode pengumpulan data dengan cara menyimak penggunaan bahasa.

Dalam proses analisis data, peneliti menggunakan metode penelitian padan intralingual. Mahsun (2007: 117-118), menjelaskan bahwa metode padan intralingual adalah metode analisis yang menghubungbandingkan unsur-unsur bahasa dengan mengacu pada makna unsur-unsur yang berada dalam bahasa (bersifat lingual). Metode ini digunakan untuk dapat 
mengklasifikasikan data. Kemudian menurut Sugiyono (2012:91) aktivitas analisis data terdiri atas tiga langkah yaitu: reduksi data, penyajian data, dan penarikan kesimpulan. Aktivitas dalam meneliti data yaitu:

1. Reduksi Data

Reduksi data merupakan kegiatan merangkum, memilih hal-hal pokok, memfokuskan pada hal yang penting (Sugiyono, 2012: 92). Dalam hal ini dipilih data yang mengandung tindak tutur ekspresif yang digunakan para tokoh dalam anime Servant $x$ Service.

2. Penyajian Data

Penyajian data dilakukan dengan cara analisis lanjutan yang merupakan pengelompokan dari korpus-korpus tersebut. Pengklasifikasian korpus yang telah ditemui kemudian dimasukan ke dalam kartu data. Penyajian data dilakukan pembahasan kesesuaian antara teori dengan data yang sudah ditemukan.

3. Penarikan Simpulan

Pada tahap akhir dalam kegiatan menganalisis, kegiatan menyimpulkan atau generalisasi analisis awal dan lanjutan yakni memberi penjelasan dari masing-masing korpus, serta mencari tambahan dan temuan yang ada kemudian ditarik sebuah simpulan sementara dan dapat menjadi valid saat ditemukan bukti-bukti yang mendukung. Selain itu, penarikan simpulan yang dilakukan harus menjawab semua rumusan masalah yang sudah ditentukan.

\section{Hasil dan Pembahasan Hasil Penelitian}

Berdasarkan pengamatan tindak tutur ekspresif dalam anime Servant $x$ Service yang mengacu pada Searle (1979), yang menyatakan bahwa tindak tutur ekspresif merupakan tindak tutur yang berfungsi untuk mengekspresikan atau memberitahukan sikap psikologis dari penutur, yaitu ditemukan sebanyak 23 data. Kesopanan positif yang ditemukan sebanyak 17 data dan kesopanan negatif sebanyak 6 data. Adapun bentuk tindak tutur ekspresif dari 23 data yang ditemukan terdapat tiga bentuk tindak tutur ekspresif, yaitu tindak tutur langsung literal sebanyak 17 data, tindak tutur tidak langsung literal sebanyak 3 data dan tindak tutur langsung tidak literal sebanyak 3 data.

Di dalam pembahasan, akan dibahas mengenai kesopanan dan bentuk tindak tutur ekspresif yang diambil dari dialog percakapan antara tokoh-tokoh dalam anime Servant $x$ Service. Dari dialog tersebut akan dipaparkan mengenai situasi pada dialog yang mengandung tindak tutur ekspresif tersebut.

\section{1) Tindak Tutur Ekspresif Mengeluh}

Yamagami : 自己紹介のたびに

$$
\text { ヘこみます。 }
$$

: jikoshoukai no tabi ni

hekomimasu.

:'Setiap kali menyebut nama, aku jadi lemas'.

:その愛すごく重たいです。

: Sono ai sugoku omotaidesu.

: 'Cintanya terasa sangat berat'.

: いいな 沙耶って名前

\section{: Iina sayatte nama}

: 'Namamu enak ya... Hanya Saya'.

Konteks percakapan antara Yamagami dan Miyoshi terjadi di kantor tempat mereka bekerja. Miyoshi menyapa Yamagami kemudian menanyakan apa yang terjadi dengannya. Yamagami berkata kepada Miyoshi bahwa dia menjadi lemas saat namanya disebut oleh orang-orang yang bekerja dikantor. Yamagami mempunyai nama yang panjang sehingga ia hanya memperkenalkan diri dengan nama Yamagami saja. Ketika orang-orang mengetahui nama panggilannya Lucy ia menjadi mengeluh karena sebuah nama. Miyoshi yang mengatakan bahwa nama itu adalah tanda bahwa Yamagami dilahirkan dengan penuh cinta. 
Namun Yamagami mengeluh bahwa cinta itu sungguh berat karena ia mempunyai nama yang panjang.

Analisis:

Tuturan yang diucapkan oleh penutur (Yamagami) dengan mitra tutur (Miyoshi) yang memiliki fungsi tindak tutur mengeluh. Adapun keluhan penutur terhadap mitra tutur dapat ditinjau dari konteks, bahasa dan tujuan tuturan yang digunakan sesuai dengan teori yang diungkapkan oleh Leech (1993). Hubungan antara penutur dan mitra tutur adalah rekan kerja di kantor. Dari segi konteks tuturan, penutur memiliki masalah terhadap namanya yang panjang.

Fungsi tuturan mengeluh dapat ditandai dari kata / hekomul yang memiliki makna 'lelah'. Dari segi konteks, kalimat tersebut dikatakan kepada Miyoshi setelah Yamagami bertemu dan memperkenalkan diri kepada karyawan lain. Yamagami merasa lelah karena setiap kali bertemu dengan teman kantor lain selalu dipanggil Lucy. Kata /hekomul menunjukkan bahwa Yamagami merasa tidak nyaman dipanggil dengan nama depannya.

Kata /hekomu/ diperkuat dengan kata /sugoku omotaidesul yang memiliki makna 'sungguh berat'. Kalimat yang diucapkan oleh penutur tersebut menandakan rasa kecewa atas kenyataan yang terjadi bahwa ia merasa mempunyai beban berat atas nama yang dimilikinya. Kemudian kata /iina sayatte namae/ yang memiliki makna 'Namamu enak ya... Hanya Saya' kalimat tersebut menunjukkan iri terhadap mitra tutur karena mempunyai nama yang pendek. Hal tersebut sejalan dengan pendapat Searle (1979) bahwa penutur mengungkapkan sikap psikologisnya terhadap mitra tutur bahwa penutur mengeluh karena terdapat sebuah perbedaan antara harapan yang diinginkan oleh penutur dengan kenyataan yang terjadi yang disebabkan nama penutur dan merasa tidak nyaman sehingga menimbulkan tindak tutur mengeluh atas kesusahan yang penutur rasakan terhadap nama yang dimilikinya.

Berdasarkan strategi kesopanan, tindak tutur ekspresif mengeluh yang diutarakan oleh penutur terhadap mitra tutur menunjukkan strategi kesopanan positif. Pada data 1 menunjukkan tuturan ekspresif yang mengancam muka positif mitra tutur dengan keluhan (Brown \& Levinson 1978) maka dari itu penutur menggunakan strategi kesopanan positif untuk mengurangi daya ancam muka positif mitra tutur.

Data ini termasuk klasifikasi tindak tutur ekspresif mengeluh berdasarkan kesopanan dengan menggunakan strategi positif 3 menurut Brown \& Levinson (1978) yaitu meningkatkan rasa tertarik terhadap mitra tutur agar mengurangi rasa kekecewaan mitra tuturnya. Hal tersebut dikarenakan pada saat Yamagami mengeluh, mitra tutur menyemangati penutur agar tidak mengeluh lagi.

Tuturan tersebut menggunakan jenis tuturan langsung tidak literal, Hal tersebut sesuai dengan pendapat Wijana dan Rohmadi (2011) bahwa tuturan tersebut memiliki makna yang tidak sesuai dengan kata-kata yang menyusunnya. Kata /iina/ yang diungkapkan oleh penutur memiliki arti 'bagus ya' yang ditunjukkan kepada nama yang dimiliki oleh Miyoshi. Kata tersebut menunjukkan rasa iri yang dirasakan Yamagami sehingga menunjukkan keluhan.

\section{2) Tindak Tutur Ekspresif Menyindir}

$\begin{array}{ll}\text { Direktur } & : \text { 君は偉いな... } \\ & : \text { Kimi wa eraina... } \\ \text { Miyoshi } & : \text { Kamu luar biasa ya'. } \\ & : \text { 何がですようか? } \\ & : \text { nani ga desyuyouka? } \\ \text { Direktur } & : \text { 'Apanya?’ } \\ & : \text { 服装が地味でだよ。 }\end{array}$

若い臨時職員は花瓶になりがちだからね。もつと格好を考えて欲 しいものだ。 


\section{: Fukusou ga jimi de dayo. Wakai rinji shouku wa kabin ni narigachi sakarane. Motto kakkou o kangaete shoshii moono da. \\ :'Penampilanmu sangat sederhana, pegawai lainnya yang masih muda cenderung tampil mewah. Harusnya lebih memerhatikan masalah penampilan'.}

Tuturan antara Direktur kantor dan Chihaya terjadi di kantor tempat Yamagami bekerja. Direktur kantor menegur sapa mitra tutur dengan memanggil nama mitra tutur kemudian direktur tersebut mengungkapkan tuturan memuji tetapi bersifat mengkritik pakaian yang digunakan oleh Chihaya.

Analisis:

Tuturan antara Direktur (penutur) dan Chihaya (mitra tutur) memiliki fungsi tuturan menyindir. Tuturan menyindir terhadap mitra tutur dapat ditinjau dari konteks, bahasa dan tujuan tuturan yang digunakan sesuai dengan yang diungkapkan oleh Leech (1993). Tuturan ekspresif menyindir yang diungkapkan penutur memiliki tujuan untuk mengkritik pakaian mitra tutur.

Pada tuturan /Kimi wa eraina./'Kamu luar biasa ya' Ungkapan tersebut menunjukkan penutur membuka topik percakapan dengan memuji mitra tutur. Mitra tutur yang tidak mengerti tujuan dari tuturan tersebut bertanya kepada penutur. Kemudian Penutur memperjelas maksud tuturan ekspresifnya dengan mengatakan / fukusou ga jimi de dayo. Wakai rinji shouku wa kabin ni narigachi sakarane. Motto kakkou o kangaete shoshii moono da/ yang memiliki makna /penampilanmu sangat sederhana, pegawai honorer lainnya yang masih muda cenderung tampil mewah. Harusnya lebih memerhatikan masalah penampilan'. Ungkapan yang diungkapkan penutur merupakan tuturan ekspresif menyindir dengan membandingkan pakaian mitra tutur dengan pakaian pegawai lain yang cenderung tampil mewah. Pada data ini dikatakan tuturan menyindir karena terdapat ungkapan kritikan yang dikatakan direktur terhadap pegawai mengenai pakaian yang dikenakan.

Tuturan ekspresif menyindir dalam data 3 termasuk ke dalam kategori tindakan mengancam muka positif mitra tutur karena mengungkapkan kritikan (Brown \& Levinson: 1978). Tindakan tersebut bisa mengancam muka mitra tutur, dalam tuturan yang diungkapkan penutur ditemukan strategi kesopanan yang digunakan untuk mengurangi daya mengancam muka positif. Adapun strategi yang digunakan adalah strategi positif 3 yaitu meningkatkan rasa tertarik terhadap mitra tutur. Hal tersebut dapat dilihat dari kalimat pujian yang diungkapkan dari penutur yang mengungkapkan kata /erail yang berarti luar biasa dengan penampilan yang sederhana yang dikenakan mitra tutur.

Tindak tutur ekspresif menyindir pada data 3 menggunakan jenis tuturan langsung tidak literal. Hal tersebut sesuai dengan pendapat Wijana dan Rohmadi (2011) bahwa tuturan tersebut diutarakan dengan modus tuturan yaitu modus menyindir, tetapi kata-kata yang menyusunnya tidak memiliki makna yang sama dengan penutunya. Kalimat yang diungkapkan menunjukkan kata pujian dengan penampilan penutur yang sederhana. Namun kata sederhana tersebut menunjukkan makna yang berbeda karena penutur membandingkan pakaian pegawai lain yang lebih modern dan menyuruh mitra tutur memperhatikan penampilannya. Makna yang bisa didapat dari tuturan tersebut yaitu penutur memiliki tujuan menyindir dengan mengkritilk pakaian agar mitra tutur mengenakan pakaian yang lebih modern seperti pegawai lainnya. 
JPBJ, Vol. 7 No. 1, Februari 2021

ISSN: 2613-9618

\section{3) Tindak Tutur Ekspesif Memuji}

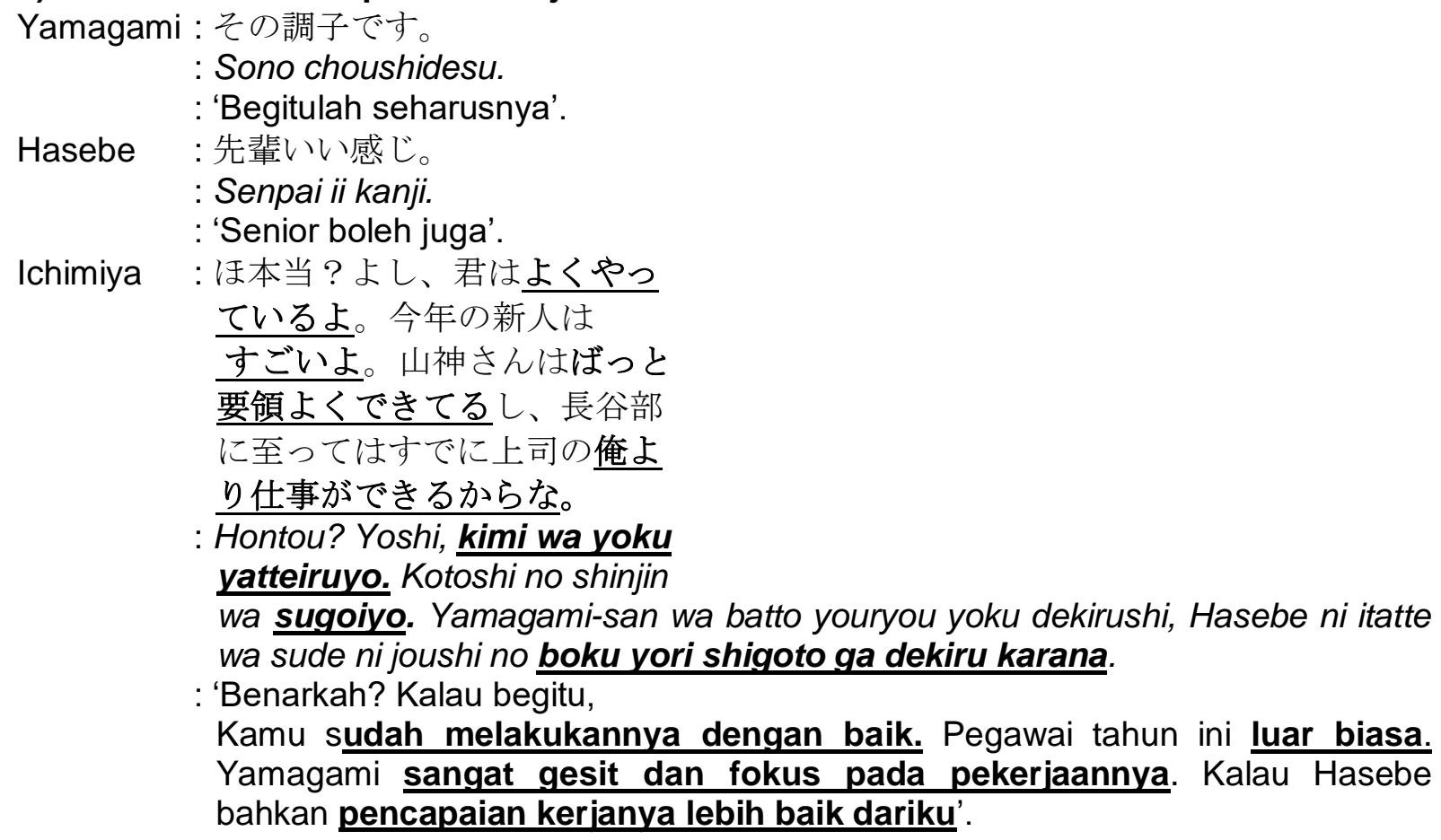

Konteks percakapan antara Ichimiya, Yamagami, Miyoshi dan Hasebe terjadi di kantor. Miyoshi yang sedang menceritakan pengalaman saat bekerja sebagai karyawan baru dengan Yamagami, Hasebe dan Ichimiya. Miyoshi merasa tertekan karena merasa tidak bisa bekerja dengan baik. Maka dari itu Yamagami dan Hasebe merasa kalau Ichimiya harus melakukan sesuatu. Dalam data ini dapat ditinjau dari konteks, bahasa dan tujuan.

Analisis:

Percakapan yang terjadi antara Ichimiya dan Miyoshi di kantor terdapat tindak tutur ekspresif memu yaitu ditinjau dari segi bahasa, tuturan /kimi wa yoku yatteiruyo/ yang memiliki makna 'kamu sudah bekerja dengan baik'. Tuturan memuji berikutnya dapat ditemukan pada kata /sugoiyo/ yang memiliki makna 'luar biasa. Ichimiya merasa bahwa pegawai kantor tahun ini yang bekerja di kantor kinerjanya luar biasa.

Selanjutnya tuturan /batto youryou yoku dekirushi/ yang memiliki makna 'sangat gesit dan fokus pada pekerjaannya' Ichimiya memuji Yamagami berdasarkan kemampuan bekerja Yamagami yang gesit dan fokus pada pekerjaannya. Selanjutnya terdapat kata /boku yori shigoto ga dekiru kara na/ yang memiliki makna 'kerjanya lebih baik dariku' tujuan awal memuji adalah untuk membuat Miyoshi merasa percaya diri atas kemampuan bekerjanya sebagai pegawai baru, kemudian dilanjutkan dengan memberikan pujian kepada Hasebe dan Yamagami. Berdasarkan kalimat yang diucapkan oleh Ichimiya, hal ini sejalan dengan pendapat Leech (1991) bahwa sesuai dengan aspek situasi ujaran yang menunjukkan bahwa tuturan pada data ini mengandung tindak tutur ekspresif memuji.

Dari tuturan ekspresif yang diutarakan mengandung prinsip kesopanan positif. Hal itu sejalan dengan pendapat Brown \& Levinson (1978) bahwa kesopanan tindak tutur ekspresif memuji digunakan untuk mengurangi rasa kekecewaan mitra tutur yang merasa murung atas pekerjaannya. Data ini termasuk klasifikasi kesopanan positif tindak tutur ekspresif memuji menggunakan strategi 9 , yaitu membuat persepsi bahwa penutur memahami keinginan mitra tuturnya.

Tindak tutur pada data ini menggunakan jenis tuturan langsung literal karena diutarakan dengan modus tuturan dan makna yang sama dengan maksud penuturnya hal tersebut sesuai dengan pendapat Wijana dan Rohmadi (2011). Secara langsung penutur memuji kinerja mitra tutur sebagai karyawan baru yang menurutnya luar biasa. Secara literal dari makna kalimat, penutur mengungkapkan kata /yoku/ yang berarti 'dengan baik', kemudian kata /sugoil berarti 'luar biasa' (Matsuura 2005). 


\section{4) Tindak Tutur Ekspresif Meminta Maaf}

$\begin{aligned} \text { Tamu } & : \text { ちよっと早くしてよ。 } \\ & : \text { Chotto hayaku shiteyo } \\ \text { Yamagami } & : \text { 'Cepatlah sedikit'. } \\ & : \text { Sumiせん } \\ & : \text { 'Maafkan saya'. } \\ \text { Chihaya } & : \text { †九番です。 } \\ & : \text { Juukyuu ban desu. } \\ & : \text { 'Ada di meja 19'. } \\ \text { Tamu } & : \text { やったく。 } \\ & : \text { Yattaku. } \\ & : \text { Ya ampun'. }\end{aligned}$

Konteks percakapan antara Yamagami, tamu dan Chihaya tersebut terjadi di kantor. Seorang tamu datang menghampiri Yamagami dan Chihaya. Kemudian tamu tersebut meminta buku catatan persalinan. Yamagami meminta waktu sebentar untuk mengecek di mana buku catatan persalinan tersebut dapat diambil. Namun tamu tersebut tidak sabar dan menyuruh Yamagami cepat memberitahunya. Yamagami yang kaget meminta maaf karena tidak segera memberi tahu tempat buku persalinan tersebut dapat diambil.

Analisis:

Fungsi tuturan meminta maaf dapat ditandai dari kata awal yang di ucapkan oleh mitra tutur yaitu /Chotto hayaku shiteyo/ yang memiliki makna 'bisa cepat sedikit?'. Kalimat tersebut menunjukkan sebuah kekecewaan mitra tutur terhadap penutur karena keinginannya tidak terpenuhi. Rasa kekecewaan mitra tutur diperkuat dengan kalimat /yattaku/ yang memiliki makna 'ya ampun'. Setelah Yamagami meminta maaf dan Chihaya memberitahu tempat buku catatan persalinan berada, mitra tutur mengatakan kalimat tersebut karena yang menjawab adalah Chihaya bukan Yamagami. Tindak tutur ekspresif meminta maaf yang diucapkan oleh penutur yaitu /sumimasen/ yang memiliki makna 'maafkan saya'. Penutur mengucapkan kata maaf karena sudah melakukan kesalahan dan sudah merepotkan mitra tutur. Hal itu sejalan dengan pendapat Leech (1991) berdasarkan konteks, bahasa dan tujuan penutur mengucapkan maaf.

Tindak tutur ekspresif meminta maaf yang ditemukan mengandung prinsip kesopanan negatif. Dengan demikian penutur sudah menggunakan kesopanan negatif strategi ke 6 yaitu menggunakan permohonan maaf sesuai dengan pendapat Brown \& Levinson (1978) penutur meminta maaf karena sudah melakukan kesalahan terhadapa mitra tutur untuk mengurangi pelanggaran wajah negatif mitra tutur.

Pada data ini terdapat bentuk tindak tutur ekspresif literal sesuai dengan pendapat Wijana dan Rohmadi (2011) kalimat diutarakan dengan modus tuturan dan makna yang sama dengan maksud penuturnya, yaitu meminta maaf atas kesalahannya.

\section{5) Tindak Tutur Ekspresif Membanggakan diri}

$\begin{aligned} \text { Ichimiya } & \text { : 流れって何だよ!つていうか } \\ & \text { 資料は } \\ & \text { : Nagarette nandayo! } \\ & \text { tteiuka shiryou wa.. } \\ & : \text { 'Apanya yang terjadi begitu } \\ & \text { saja? ngomong-ngomong dokumennya?' } \\ \text { Hasebe } & : \text { もう読んだ。覚えた。 }\end{aligned}$

Mou yonda! Oboeta!

'Aku sudah membaca dan menghafalnya'

Hasebe : 先輩 一つ質問あるんです

$$
\text { けど }
$$


JPBJ, Vol. 7 No. 1, Februari 2021

ISSN: 2613-9618

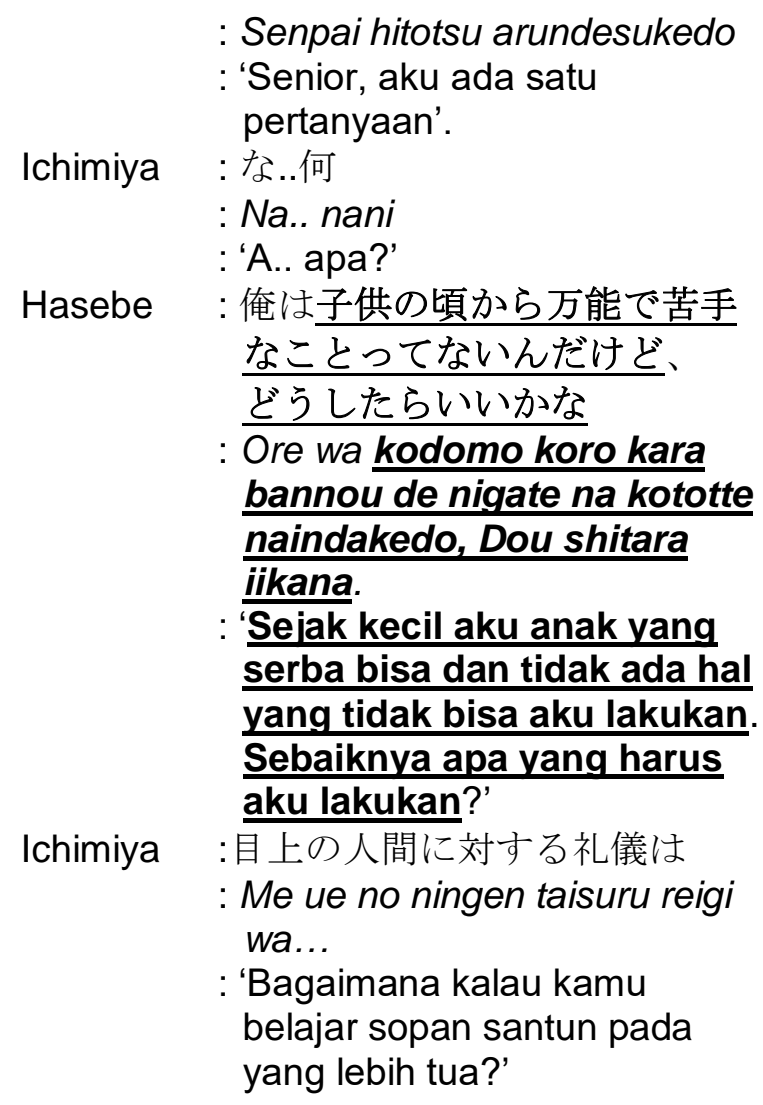

Konteks percakapan antara Hasebe dan Ichimya terjadi di kantor tempat mereka bekerja. Hasebe yang merupakan karyawan baru saat itu bertanya kepada Ichimiya yang merupakan seniornya. Hasebe berkata bahwa sejak kecil ia merupakan anak yang serba bisa dan tidak ada hal yang tidak bisa ia lakukan. Kemudian ia berkata kepada Ichimiya sebaiknya apa yang harus ia lakukan. Perkataan Hasebe tersebut mengandung makna menyombongkan diri kepada Ichimiya.

Analisis:

Pada kalimat /mou yonda! oboeta!l yang memiliki makna 'aku sudah membaca dan menghafalnya' kalimat tersebut menjadi tanda bahwa Hasebe sudah membaca dan dengan cepat menghafal dokumen yang diberikan oleh Ichimiya. Fungsi tuturan membanggakan diri dapat ditandai dari kalimat /nigate na kototte naindakedo/yang memiliki makna 'tidak ada hal yang tidak bisa aku lakukan'. Hasebe mengatakan bahwa tidak ada hal yang tidak bisa ia lakukan karena sejak kecil sudah menjadi orang yang serba bisa secara bahasa dan tujuan kalimat tersebut menunjukkan tindak tutur ekspresif membanggakan diri.

Tuturan membanggakan diri diperkuat dengan adanya kalimat /Dou shitara ii kana/ yang memiliki arti 'apa yang harus aku lakukan'. Kalimat tersebut seolah-olah penutur membutuhkan saran mitra tutur karena tidak tahu apa yang harus dia lakukan dengan kelebihannya. Namun kalimat tersebut tidak menunjukkan bahwa penutur sedang kebingungan, hal tersebut dapat dilihat dari respon mitra tutur yang memberi saran bahwa mitra tutur harus sopan kepada yang lebih tua. Sejalan dengan pendapat Leech (1991) tuturan dari penutur terhadap mitra tutur dapat ditinjau dari konteks, bahasa dan tujuan tuturan yang digunakan memiliki fungsi tindak tutur membanggakan diri

Dalam data ini, penutur menggunakan kesopanan negatif strategi ke 2 yaitu menggunakan bentuk pertanyaan dengan partikel tertentu. Penutur mengucapkan kelebihanya, dalam kalimat tersebut terdapat sebuah pertanyaan dengan menggunakan partikel tertentu yaitu /kana/ partikel tersebut menunjukan bahwa penutur menanyakan sesuatu yang masih diragukan oleh diri sendiri. Sejalan dengan pendapat Brown \& Levinson (1978) bahwa tindak tutur ekspresif membanggakan diri yang ditemukan mengandung 
prinsip kesopanan negatif agar mengurangi pelanggaran wajah negatif mitra tutur karena mengandung partikel tertentu.

Pada data ini terdapat bentuk tindak tutur ekspresif tidak langsung literal. Tuturan membanggakan diri yang diungkapkan diungkapkan secara tidak langsung dengan kalimat tanya, yaitu /doushitaraiikana/ yang memiliki makna 'sebaiknya apa yang harus aku lakukan?'. Dengan demikian, pada data ini tindak tutur membanggakan diri diungkapkan hal itu sejalan dengan pendapat Wijana dan Rohmadi (2011) bahwa modus kalimat tidak sesuai dengan maksud pengutaraannya tetapi makna kata-kata yang menyusunnya sesuai dengan yang dimaksudkan penutur.

\section{6) Tindak Tutur Ekspresif Mengucapkan Terima Kasih}

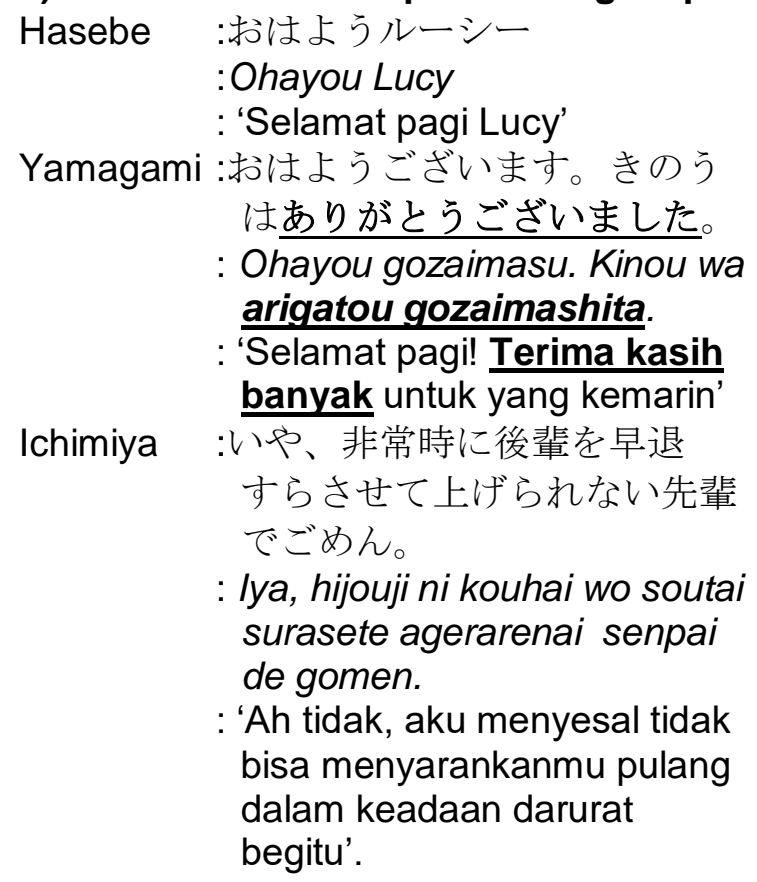

Konteks percakapan antara Ichimiya (mitra tutur) dan Yamagami (penutur) terjadi di kantor tempat mereka bekerja. Ketika Hasebe dan Ichimiya sedang bersama kemudian Hasebe menyapa Yamagami.

Analisis:

Tuturan ekspresif mengucapkan terima kasih dapat ditandai dari kalimat 'arigatou gozaimashita' yang memiliki arti /terima kasih banyak/. Dari penggunaan bahasa yang digunakan, tuturan 'arigatou gozaimashita' digunakan dalam situasi formal yaitu di kantor untuk menghormati Ichimiya yang kedudukannya sebagai atasan Yamagami. Dari tujuan tuturan kalimat tersebut diucapkan karena ingin berterima kasih atas bantuan yang sudah diberikan. Sejalan dengan pendapat Leech (1991) tuturan pada data ini berdasarkan konteks, bahasa dan tujuan tuturan menunjukkan tindak tutur ekspresif mengucapkan terima kasih.

Dari tuturan ekspresif yang diutarakan mengandung prinsip kesopanan positif. Hal tersebut sejalan dengan pendapat Brown \& Levinson (1978) bahwa kesopanan tindak tutur ekspresif mengucapkan terima kasih digunakan termasuk dalam klasifikasi kesopanan negatif dengan menggunakan strategi 5, yaitu memberikan penghormatan. Dalam Data ini, Yamagami mengucapkan terima kasih kepada Ichimiya karena kebaikan yang telah dilakukan. Tindak tutur ekspresif mengucapkan terima kasih pada data ini dilakukan dengan sopan sebagaimana atasan dan bawahan. Yamagami membungkuk sambil mengucapkan terima kasih kepada Ichimiya sehingga menunjukkan bahwa Yamagami memberi penghormatan kepada mitra tutur.

Pada data ini terdapat bentuk tindak tutur ekspresif langsung literal. Kalimat tersebut diutarakan dengan modus tuturan dan makna yang sama dengan maksud penuturnya, yaitu menyatakan tuturan mengucapkan kepada mitra tutur. Sejalan dengan pendapat Wijana dan 
Rohmadi (2011) bahwa tuturan secara langsung berdasarkan modus deklaratif yang menyatakan ketidaksukaan. Secara literal dengan modus yang sama dengan makna kata yang menyusunnya yaitu /arigatou gozaimashita/ yang memiliki makna 'terima kasih banyak'.

Dari hasil pembahasan yang sudah dilakukan, tindak tutur ekspresif meminta maaf banyak ditemukan yaitu berjumlah 6 data. Hal tersebut dikarenakan anime ini memperlihatkan interaksi antara pegawai lama dan baru maupun pegawai dan warga di kantor. Terdapat kesenjangan komunikasi antar pegawai lama dan baru dalam berinteraksi, begitu juga dengan interaksi pegawai dan warga dalam melakukan pelayanan di kantor, hal tersebut yang memicu banyaknya ungkapan tindak tutur ekspresif meminta maaf.

Terdapat strategi kesopanan yang ada di dalam tindak tutur ekspresif, strategi kesopanan tersebut dapat dianalisis berdasarkan strategi kesopanan, baik kesopanan positif maupun kesopanan negatif. Berdasarkan data yang ditemukan fungsi tindak tutur ekspresif bisa memiliki strategi kesopanan yang berbeda walaupun fungsi yang ditemukan sama. Hal tersebut dikarenakan strategi yang ditemukan dapat dianalisis berdasarkan aspek situasi ujaran yang terdapat pada setiap tuturan.

Dalam mengungkapkan tindak tutur ekspresif diidentifikasi bisa mengancam muka positif dan negatif mitra tutur. Untuk mengurangi daya ancam tersebut maka perlu digunakan strategi kesopanan untuk mengurangi daya ancam muka tersebut. Kemudian fungsi tindak tutur ekspresif berdasarkan strategi kesopanan terdapat bentuk tuturan yang ditemukan. Dalam bentuk tindak tutur ekspresif yang sama, ditemukan tindak tutur ekspresif yang berbeda. Hal tersebut terjadi karena perbedaan makna yang menyusun kata tersebut yang dianalisis berdasarkan konteks dan situasi di setiap tuturan.

\section{Simpulan dan Saran}

Berdasarkan hasil analisis dari 23 data tindak tutur ekspresif dalam anime Servant $x$ Service (episode 1 sampai 13), diperoleh 2 kesimpulan sebagai berikut: Fungsi tindak tutur ekspresif berdasarkan strategi kesopanan dalam penelitian ini adalah mengeluh, menyindir, memuji, meminta maaf, membanggakan diri, mengucapkan terima kasih sebanyak. Fungsi tindak tutur ekspresif yang banyak ditemukan adalah tindak tutur ekspresif meminta maaf sebanyak 6 data dengan strategi kesopanan positif dan negatif. Fungsi tindak tutur ekspresif banyak ditemukan karena terdapat kesenjangan komunikasi antar pegawai lama dan baru, begitu juga dengan interaksi pegawai dan warga dalam melakukan pelayanan di kantor, hal tersebut yang memicu banyaknya ungkapan tindak tutur ekspresif meminta maaf. Fungsi tindak tutur menyindir dan membanggakan diri sedikit ditemukan karena tuturan tersebut dapat mengancam muka mitra tutur. Bentuk tuturan ekspresif dalam penelitian ini adalah bentuk tindak tutur langsung literal bentuk tindak tutur tidak langsung literal, bentuk tindak tutur langsung tidak literal, dan tidak ditemukan satupun data dengan bentuk tindak tutur tidak langsung tidak literal. Dapat diketahui bahwa bentuk tindak tutur langsung literal adalah bentuk tindak tutur yang paling banyak ditemukan, karena dalam percakapan para tokoh dalam anime ini, mereka lebih cenderung mengungkapkan perasaan mereka secara lugas agar tidak terjadinya perbedaan pemahaman makna.

Berdasarkan simpulan diatas, diharapkan kepada pembaca agar dapat mencari lebih banyak lagi tentang kesopanan dari tindak tutur ekspresif. Kemudian, penelitian ini hanya membahas tentang tindak tutur ekspresif berdasarkan strategi kesopanan dalam anime Servant $x$ Service saja. Masih ada tindak tutur lainnya yang dapat diteliti, dalam anime ini. Maka dari itu, saran untuk penelitian selanjutnya agar dapat membahas tentang tindak tutur yang lainnya misalnya tindak tutur direktif atau komisif. 


\section{Daftar Pustaka}

Austin, J.L. 1962. How to do Thing With Word. New York. Oxford University Press.

Brown, Penelope \& Stephen Levinson. 1987. Politeness: Some Universals in Language Usage. Cambridge: Cambridge University Press.

Leech, Geoffrey. 1993. Prinsip-Prinsip Pragmatik. Jakarta: Universitas Indonesia.

Mahsun. 2007. Metodologi Penelitian Bahasa: Tahapan Strategi, Metode, dan Tekniknya. Jakarta: PT Raja Grafindo Persada.

Searle, Jhon R. 1979. Expression and Meaning Studies in the Theory Speech Acts. New York: Cambridge University.

Tahang, Heriyanti. 2019. "Strategi Kesopanan Berbahasa Yang Digunakan Oleh Penghuni Kos". Jurnal Noken Vol 4 (2) Halaman 201-211. Tersedia pada http://ejournal.umsorong.ac.id/index.php/jn/article/download/500/pdf (diakses pada 13 Agustus 2019).

Wijana, putu dan Muhammad Rohmadi. 2011. Analisis Wacana Pragmatik Kajian Teori dan Analisis. Cetakan ke-3. Kadipro Surakarta: Yuma Pustaka.

Yule, George. 2006. Pragmatik. Yogyakarta: Pustaka Pelajar. 